\title{
Thyroid Incidentalomas on I8F-FDG PET/CT: Clinical Significance and Controversies
}

\author{
18F-FDG PET/BT'de Tiroid Insidentalomalar: Klinik Önem ve Tartışmalar
}

William Makis', Anthony Ciarallo2

' Cross Cancer Institute, Department of Diagnostic Imaging, Edmonton, Canada

2MUHC Glen Site, Department of Nuclear Medicine, Montreal, Canada

\begin{abstract}
Objective: The purpose of the current study is to examine the incidence and clinical significance of unexpected focal uptake of 18 F-fluorodeoxyglucose (18F-FDG) on positron emission tomography/computed tomography (PET/CT) in the thyroid gland of oncology patients, the maximum standardized uptake value $\left(S U V_{\max }\right)$ of benign and malignant thyroid incidentalomas in these patients, and review the literature.

Methods: Seven thousand two hundred fifty-two 18F-FDG PET/CT studies performed over four years, were retrospectively reviewed. Studies with incidental focal 18F-FDG uptake in the thyroid gland were further analyzed.

Results: Incidental focal thyroid 18F-FDG uptake was identified in 157 of 7252 patients (2.2\%). Sufficient follow-up data ( $\geq 12$ months) were available in 128 patients, of whom 57 (45\%) had a biopsy performed and 71 had clinical follow-up. Malignancy was diagnosed in 14 of 128 patients (10.9\%). There was a statistically significant difference between the median SUV $V_{\text {max }}$ of benign thyroid incidentalomas (SUV $\max 4.8$ ) vs malignant $\left(S U V_{\max } 6.3\right)$, but the wide range of overlap between the two groups yielded no clinically useful SUV $\max$ threshold value to determine malignancy.

Conclusion: 18 F-FDG positive focal thyroid incidentalomas occurred in $2.2 \%$ of oncologic PET/CT scans, and were malignant in $10.9 \%$ of 128 patients. This is the lowest reported malignancy rate in a North American study to date, and significantly lower than the average malignancy rate (35\%) reported in the literature. Invasive biopsy of all 18F-FDG positive thyroid incidentalomas, as recommended by some studies, is unwarranted and further research to determine optimal management is needed. There was no clinically useful SUV $V_{\max }$ cut-off value to determine malignancy and PET/CT may not be a useful imaging modality to follow these patients conservatively.

Keywords: Thyroid incidentaloma, thyroid carcinoma, 18F-fluorodeoxyglucose, 18F-FDG, positron emission tomography, PET,
\end{abstract} $\mathrm{PET} / \mathrm{CT}$

Öz

Amaç: Bu çalışmanın amacı onkoloji hastalarının 18F-florodeoksiglukoz (18F-FDG) pozitron emisyon tomografisi/bilgisayarlı tomografisinde (PET/BT) tesadüfen saptanan tiroid bezi fokal tutulumunun insidansını ve klinik önemini ve bu hastalarda benign ve malign tiroid insidentalomalarının maksimum standardize tutulum değerini (SUV $\left.\mathrm{maks}_{\mathrm{s}}\right)$ değerlendirmek ve literatürü gözden geçirmektir.

Yöntem: Dört yıl boyunca yapılmış 7252 18F-FDG PET/BT incelemesi retrospektif olarak değerlendirildi. Tiroid bezinde insidental fokal 18 F-FDG tutulumu olanlar incelemeye dahil edildi.

Address for Correspondence: William Makis MD, Cross Cancer Institute, Department of Diagnostic Imaging, Edmonton, Canada Phone: 7804328760 E-mail: makisw79@yahoo.com ORCID ID: orcid.org/0000-0003-0241-3426 Received: 13.01.2017 Accepted: 22.06.2017 


\section{Öz}

Bulgular: 7252 hastanın 157'sinde insidental fokal tiroid 18F-FDG tutulumu saptandı (\%2,2). Yüz yirmi sekiz hastada yeterli takip verisi mevcuttu ( $\geq 12$ ay), bunların 57'sine (\%45) biyopsi uygulanmış ve 71'i klinik olarak takip edilmişti. Yüz yirmi sekiz hastanın 14'ünde malignite saptanmıştı $(\% 10,9)$. Benign tiroid insidentalomalarının ortanca maksimum standardize tutulum değeri (SUV maks 4,8) ile malign tiroid insidentalomalarının değerleri (SUV maks 6,3) arasında istatistiki olarak anlamlı fark saptandı, ancak her iki grup arasındaki geniş aralıklı örtüşme olduğundan malignite saptamada klinik olarak yararlı olabilecek bir SUV $V_{\text {maks }}$ eşik değeri saptanmadı.

Sonuç: 18F-FDG pozitif fokal tiroid insidentaloması onkolojik PET/BT taramalarının \%2,2'sinde görüldü ve 128 hastanın \%10,9'unda malignite mevcuttu. Bu oran günümüze kadar Kuzey Amerika çalışmalarında bildirilen en düşük düzeydir ve literatürde bildirilen ortalama malignite oranından (\%35) ciddi şekilde azdır. Bazı çalışmalarda önerildiği gibi tüm 18F-FDG pozitif tiroid insidentalomalarının invazif biyopsisi sağlam bir temele dayanmamaktadır, optimal yaklaşımı belirlemek için ileri

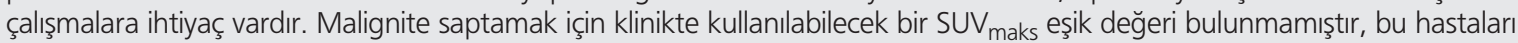
konservatif olarak takip etmek için PET/BT yararlı bir modalite olmayabilir.

Anahtar kelimeler: Tiroid insidentaloma, tiroid karsinoma, 18F-florodeoksiglukoz, 18F-FDG, pozitron emisyon tomografisi, PET, PET/BT

\section{Introduction}

One of the main challenges that face positron emission tomography/computed tomography (PET/CT) readers is the interpretation of foci of abnormal 18F-FDG uptake in unexpected anatomic locations $(1,2,3,4,5,6,7,8,9,10)$. The thyroid gland is the best studied anatomic location of incidental 18F-FDG uptake, with well over 30 studies examining the clinical significance of thyroid incidentaloma (11-22), including 3 systematic reviews (11-13). However, thyroid incidentalomas still remain a source of controversy in the literature.

The malignancy rates in thyroid incidentalomas range in the literature from $10 \%$ up to $64 \%$. Three systematic reviews have reported a pooled malignancy rate of 33-35\%. One major point of contention with most of these studies is that only a small subset of patients is biopsied (usually patients with a high clinical suspicion of malignancy), and most thyroid incidentaloma patients are not investigated or followed further. The largest systematic review of thyroid incidentaloma studies (27 studies) revealed a biopsy rate of only $35 \%$. Many papers in the literature recommend that all thyroid incidentaloma patients be invasively biopsied, however this recommendation is based on a malignancy rate derived from a subset of non-randomly selected thyroid incidentaloma patients.

There is also controversy over the utilization of $S U V_{\max }$ to differentiate benign from malignant thyroid incidentalomas. Many studies have made attempts to determine an optimal cut-off $S U V_{\max }$ value for differentiating benign from malignant lesions. Only half of these studies have managed to detect a statistically significant difference. Three metaanalyses reflect these conflicting results.

The purpose of this retrospective review was to determine the incidence of unexpected focal uptake of 18F-FDG in the thyroid gland of oncology patients (with no prior history of thyroid cancer) and what proportion of these cases were malignant. We also evaluated the feasibility of using $S U V_{\max }$ to identify malignant causes of incidental focal thyroid 18F-FDG uptake and investigated whether a clinically useful cut-off value of SUV $\max$ could be determined.

\section{Materials and Methods}

A retrospective review of 7252 oncologic 18F-FDG PET/ CT studies performed over the course of 48 months (January 1, 2006-December 31, 2009) was done. PET/ CT studies with incidental focal 18F-FDG thyroid gland uptake, regardless of corresponding CT findings, formed the basis for this review.

One hundred fifty-seven ( $n=157)$ patients out of 7252 (2.2\%) had unexpected focal 18 F-FDG thyroid uptake and comprised the study group. We excluded patients who had a history of a previous thyroid malignancy or predisposing condition (e.g. Cowden syndrome) $(n=6)$, and patients who had insufficient follow-up data (less than 12 months) $(n=23)$. The remaining 128 patients comprised the study group that was evaluated further to determine the clinical significance of unexpected focal 18F-FDG thyroid gland uptake. The primary malignant diagnoses of these 128 patients are listed in Table 1.

\section{PET/CT Examination and Interpretation}

The PET scanner used in this study was the Discovery ST with a 16-slice CT (GE Healthcare, WI, USA). 18F-FDG $\mathrm{PET} / \mathrm{CT}$ exams were performed according to routine institutional protocol. After a minimum of 4 to 6 hours of fasting, patients waited in a quiet and dark room just prior to their exam. Serum glucose levels were tested and $0.22 \mathrm{mCi}(8.14 \mathrm{MBq}) / \mathrm{kg}$ dose of $18 \mathrm{~F}-\mathrm{FDG}$ was injected (to a maximum dose of $20 \mathrm{mCi}$, or $740 \mathrm{MBq}$ ). Approximately 60 minutes after injection of $18 \mathrm{~F}-\mathrm{FDG}$, PET portion of the study was acquired in 2D from the base of the skull to the proximal thighs. Data were acquired 
for 4-5 min per bed position (depending on patient body weight). CT portion of the study was acquired (140 kVp, 90-110 mA) with a rotation time of $0.8 \mathrm{~s}$, pitch $1.75: 1$ and detector row configuration of $16 \times 0.625 \mathrm{~mm}$. The patient was breathing normally during both PET and CT acquisitions.

The PET data were reconstructed iteratively with orderedsubsets expectation maximization algorithm (21 subsets, 2 iterations). PET emission data were corrected for photon attenuation effects using $\mathrm{CT}$ images. PET/CT exams were interpreted by two nuclear medicine board certified physicians independently on a dedicated Xeleris 2.0 workstation (GE Healthcare, Waukesha, WI, USA). Any unexpected focal 18 F-FDG thyroid gland uptake was noted and maximum standardized uptake value $\left(S \cup V_{\max }\right.$ corrected for body weight) was measured using a spherical region of interest (ROI) at the site of most intense 18F-FDG accumulation.

Table 1. Study population $(n=128)$

\begin{tabular}{lll}
\hline $\begin{array}{l}\text { Primary } \\
\text { malignancy }\end{array}$ & $\mathbf{n}(\%)$ & $\begin{array}{l}\text { Malignant } \\
\text { incidentaloma }\end{array}$ \\
\hline Lymphoma & $24(18.8)$ & 2 \\
Rectal & $14(10.9)$ & 1 \\
Unknown origin & $14(10.9)$ & 1 \\
Lung & $12(9.4)$ & 1 \\
Sarcoma & $10(7.8)$ & \\
Cervical & $8(6.3)$ & \\
Colon & $8(6.3)$ & 2 \\
Breast & $7(5.5)$ & 1 \\
Melanoma & $6(4.7)$ & 2 \\
Uterine & $4(3.1)$ & \\
Gastric & $3(2.3)$ & 1 \\
GIST & $3(2.3)$ & 1 \\
Dermatomyositis & $2(1.6)$ & \\
Neuroendocrine & $2(1.6)$ & \\
Vulvar & $2(1.6)$ & \\
Brain & $1(0.8)$ & \\
Desmoid & $1(0.8)$ & \\
Esophageal & $1(0.8)$ & \\
Hepatocellular & $1(0.8)$ & \\
Ovarian & $1(0.8)$ & \\
Pancreatic & $1(0.8)$ & \\
Prostate & $1(0.8)$ & \\
Pseudomyxoma p. & $1(0.8)$ & \\
Renal & $1(0.8)$ & \\
\hline GIST: Gastrointestinal stromal tumor & \\
\hline & & \\
\hline
\end{tabular}

\section{Diagnosis}

Histopathologic evaluation or clinical follow-up (with or without serial PET/CT examinations) over a time period of at least 12 months determined the final diagnosis of either benign thyroid incidentaloma or malignant thyroid incidentaloma. Histological sampling was available in 57 of 128 patients and the other 71 patients were assessed clinically over a minimum period of 12 months or more, with a mean clinical follow-up time of 28 months (range: 12-70 months). Global clinical assessment comprised a physical examination and evaluation of all available biochemical and diagnostic imaging studies.

\section{Statistical Analysis}

The Wilcoxon-Mann-Whitney test was used to compare the 18F-FDG PET/CT SUV between benign and malignant thyroid lesions. Numeric data were expressed as median \pm interquartile range (IQR). P values of less than 0.05 were considered to indicate a statistically significant difference.

Ethical statement: The study was approved by an institutional review board or equivalent and has been performed in accordance with the ethical standards laid down in the 1964 Declaration of Helsinki and its later amendments. All subjects in the study gave written informed consent or the institutional review board waived the need to obtain informed consent.

\section{Results}

Out of 128 patients included in the study, there were 31 men and 97 women. One hundred fourteen (89.1\%) were diagnosed with a benign thyroid process and 14 (10.9\%) were diagnosed with a thyroid malignancy. The mean age of patients with benign thyroid lesions was 62.8 years, compared to 57.1 years for patients with malignant thyroid lesions. A total of 154 individual 18F-FDG positive thyroid lesions were identified in these 128 patients. The locations of the thyroid lesions are given in Table 2.

Histological evaluation was available in 57 of 128 patients. Fourteen of 57 were malignant (11 papillary, 1 follicular, 1 lymphoma and 1 metastasis) and 43 of 57 were benign (23 Hurthle cell metaplasia, 11 nodular goiter, 5 benign epithelium, 2 thyroiditis, 2 follicular adenoma) (Table 3). The mean $S U V_{\text {max }}$ of each lesion type is given in Table 3.

The remaining 71 patients were followed clinically. In addition to global clinical assessment, PET/CT follow-up

Table 2. Location of thyroid incidentalomas

\begin{tabular}{lll}
\hline Total ${ }^{18 F-F D G ~}(+)$ lesions & $\mathbf{n = 1 5 4}$ & $\%$ \\
\hline Left & 73 & 47.4 \\
Right & 77 & 50.0 \\
Isthmus & 4 & 2.6 \\
Bilateral & 26 & 16.9
\end{tabular}


studies were available in 29 of 71 patients, and the results of follow-up PET/CT SUV $\max$ of incidental focal thyroid uptake are summarized in Table 4.

There was a statistically significant difference between the median SUV $V_{\max }$ values in benign thyroid incidentalomas (median SUV $\max$ 4.8) versus malignant lesions (median $\left.S U V_{\max } 6.3\right)$, $p$ value $=0.03$, Wilcoxon Mann Whitney-U test (Table 5). However, there was a significant overlap between the ranges of benign and malignant thyroid incidentalomas with benign $S U V_{\max }$ values ranging from 2.1-30.5, and malignant $S U V_{\max }$ values ranging from 3.4 to 28.1.

Table 3. Biopsied thyroid incidentalomas $(n=57)$

\begin{tabular}{lll}
\hline Malignant $\mathbf{( n = 1 4 )}$ & $\mathbf{n}$ & Mean $_{\mathbf{S U V}}$ \\
\hline Papillary carcinoma & 11 & 9.3 \\
Follicular carcinoma & 1 & 8.3 \\
Lymphoma & 1 & 9.9 \\
Metastasis (renal cell) & 1 & 4.2 \\
\hline Benign (n=43) & $\mathbf{n}$ & ${\text { Mean } \mathbf{S U V}_{\text {max }}}$ \\
\hline Hurthle cell metaplasia & 23 & 5.6 \\
Nodular goiter & 11 & 5.3 \\
Benign epithelium & 5 & 4.3 \\
Thyroiditis & 2 & 6.8 \\
Follicular adenoma & 2 & 3.8
\end{tabular}

Table 4. Clinical follow-up

\begin{tabular}{|c|c|}
\hline Type of follow-up & $(n=71)$ \\
\hline Clinical follow-up only & 42 \\
\hline Clinical and PET/CT follow-up & 29 \\
\hline Increased SUV $V_{\max }$ on follow-up & 8 \\
\hline Same SUV $\max$ on follow-up & 2 \\
\hline Decreased SUV $V_{\max }$ on follow-up & 15 \\
\hline Resolved 18F-FDG uptake & 4 \\
\hline
\end{tabular}

PET/CT: Positron emission tomography/computed tomography
A few potential SUV $V_{\max }$ cut-offs were examined and a kappa statistic was calculated for each value to see which would maximize sensitivity and specificity. The SUV $\max$ cutoff with the highest kappa coefficient is provided (Table 6). These calculations were performed to determine if there was a satisfactory SUV $V_{\max }$ cut-off to differentiate benign thyroid lesions from malignant ones.

A receiver-operating-characteristic (ROC) curve analysis of sensitivities and specificities was performed to determine a clinically useful $S U V_{\max }$ cut-off value to aid in differentiating between benign and malignant lesions (Figure 1). PET/CT image examples of four patients with incidental thyroid uptake and their biopsy results, are provided in Figure 2.

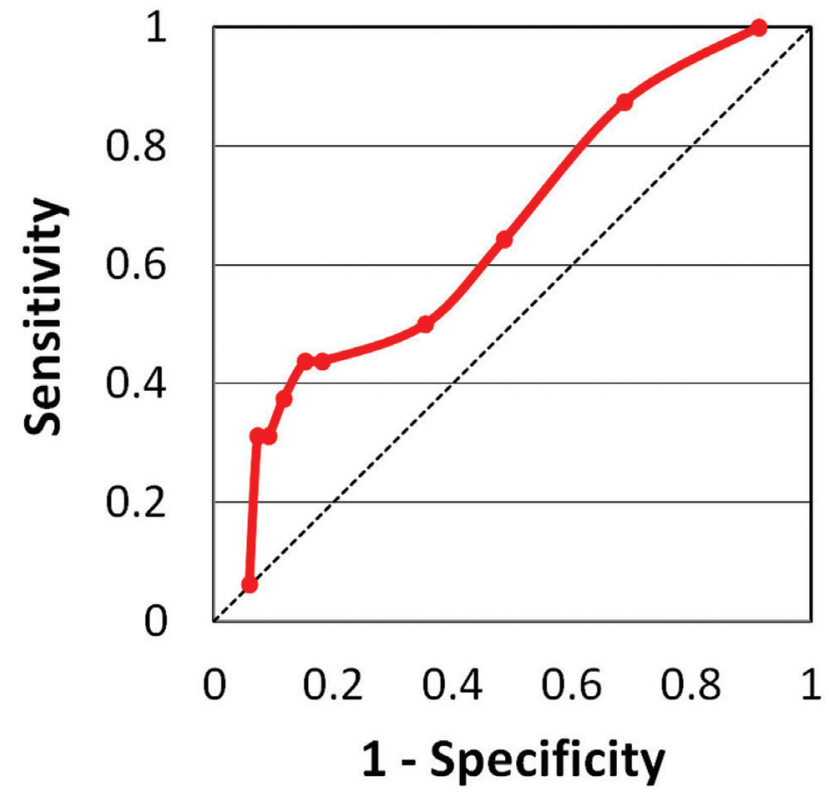

Figure 1. Receiver-operating-characteristic curve with sensitivity (y-axis) versus 1 -Specificity (x-axis) shows no satisfactory value for $S U V_{\max }$ to differentiate benign from malignant thyroid incidentalomas

Table 5. Thyroid lesion analysis

\begin{tabular}{|c|c|c|c|}
\hline & Benign $(n=138)$ & Malignant $(n=16)$ & p value \\
\hline Mean age $[y]$ (SD) & $62.8(13.6)$ & $57.1(14.2)$ & 0.14 \\
\hline Median age [y] (IQR) & $63.5(53.0 ; 72.0)$ & $56.5(49.0 ; 69.0)$ & 0.19 \\
\hline \multicolumn{4}{|l|}{$\mathrm{SUV}_{\max }$} \\
\hline Mean (SD) & $5.9(3.6)$ & $8.6(6.1)$ & 0.10 \\
\hline Median (IQR) & $4.8(3.6 ; 6.9)$ & $6.3(4.6 ; 11.7)$ & 0.03 \\
\hline Range (min.; max.) & $(2.1 ; 30.5)$ & $(3.4 ; 28.1)$ & \\
\hline \multicolumn{4}{|l|}{ Follow-up } \\
\hline Months (min.; max.) & $28(12 ; 70)$ & $n / a$ & - \\
\hline
\end{tabular}




\section{Discussion}

Incidental and unexpected focal uptake of 18F-FDG in oncologic PET/CT studies has been well studied in anatomic locations such as the breast, adrenal, gastrointestinal, parotid, prostate and thyroid glands $(1,2,3,4,5,6,7,8,9,10)$. The thyroid gland is probably the best studied location of incidental 18F-FDG uptake on PET/CT, however, it remains a source of significant controversy. In recent years, three systematic reviews have been published, examining thyroid incidentaloma literature over the past 15 years, including an analysis of 18 papers by Shie et al. (11), 22 papers by Soelberg et al. (12), and 27 papers by Bertagna et al. (13). Although these three meta-analyses showed similar conclusions, the issue of the clinical significance of 18F-FDG positive thyroid incidentalomas has not been settled.

In our review of 7252 consecutive oncologic PET/CT studies, incidental focal thyroid 18F-FDG uptake was identified in $2.2 \% \quad(n=157)$ of patients. This is within the range reported in the literature, with reports ranging from 0.2 to $8.9 \%$. Shie et al. (11) reported 1\% in 55,160 PET studies, Soelberg et al. (12) reported $1.6 \%$ in 125,754 PET studies and Bertagna et al. (13) reported a pooled incidence of $2.5 \%$ in 147,505 PET studies.

The rate of malignancy of thyroid incidentalomas varies tremendously in the literature from $10 \%$ to $64 \%(14,15)$ and remains a source of controversy. The rate of malignancy for our cohort was $10.9 \%$. The mean malignancy rate was reported as 33.2\% in the Shie et al. (11) review, as 34.8\% by Soelberg et al. (12), and as $34.6 \%$ by Bertagna et al. (13). The concordance of these meta-analysis results is not surprising as many of the same thyroid incidentaloma papers were examined by all three reviews. However, these meta-analyses did not examine possible reasons why thyroid incidentaloma malignancy rates varied so much in the literature (10 to 64\%).

Most published studies included in the three meta-analyses did not have histopathologic correlation or clinical followup on the majority of thyroid incidentaloma patients. In fact, the reported malignancy rates were usually calculated from a subset of biopsied patients who were biopsied most likely due to a high clinical suspicion of malignancy, which yielded, unsurprisingly, high malignancy rates. Soelberg et al. (12) reported a pooled biopsy rate of $46 \%(923 / 1994)$, and Shie et al. (11) reported a biopsy + follow-up rate of $56 \%$ (322/571). The largest meta-analysis by Bertagna et al. (13) reported a biopsy rate of only 35\% (1308/3727) and noted that in the majority of the studies, the proportion of 18 F-FDG positive thyroid incidentalomas that had further investigations was "inferior". Shie et al. (11) expressed that the malignancy rate in the $44 \%$ of thyroid incidentalomas that were not investigated would be similar to the malignancy rate of those who were biopsied because of similar demographic characteristics in the two groups. This assumption is flawed. If the patients chosen for biopsy had been chosen randomly, then the assumption may have had merit, but biopsied patients were not chosen randomly. Studies generally do not provide any explanations of how

Table 6. Malignancy vs. SUV max $_{\text {cut-off (Receiver-operating-characteristic) }}$

\begin{tabular}{lllll}
\hline SUV cut-off & Sens $(\mathbf{9 5} \% \mathbf{C l})$ & Spec $(\mathbf{9 5} \% \mathbf{C l})$ & PPV (95\% Cl) & NPV (95\% Cl) \\
\hline 5.0 & $69(42-88)$ & $51(43-60)$ & $14(8-24)$ & $93(85-98)$ \\
6.0 & $50(26-75)$ & $65(56-73)$ & $14(7-26)$ & $92(85-96)$ \\
$8.3^{*}$ & $44(21-69)$ & $85(78-90)$ & $25(11-45)$ & $93(87-97)$ \\
\hline
\end{tabular}

*Kappa=0.74, NPV: Negative predictive value, PPV: Positive predictive value, Cl: Confidence interval

Table 7. Thyroid incidentaloma studies with biopsy rates $>\mathbf{8 0} \%$

\begin{tabular}{lllllllll}
\hline Ref & Year & Author & Country & Incidentaloma & $\begin{array}{l}\text { Malignant/ } \\
\text { biopsied }\end{array}$ & $\begin{array}{l}\text { Reported } \\
\text { malignancy } \\
\text { rate }\end{array}$ & $\begin{array}{l}\text { Biopsied } \\
\text { rate }\end{array}$ & Issues/problems \\
\hline$(14)$ & 2003 & Hsieh & Taiwan & $12 / 477$ & $1 / 10$ & $\mathbf{1 0} \%$ & $83 \%(10 / 12)$ & Healthy volunteers only \\
$(16)$ & 2005 & Chen & Taiwan & $60 / 4803$ & $7 / 50$ & $\mathbf{1 4} \%$ & $83 \%(50 / 60)$ & \\
$(17)$ & 2007 & King & USA & $22 / 15711$ & $3 / 21$ & $\mathbf{1 4} \%$ & $95 \%(21 / 22)$ & Unknown type of patient \\
$(19)$ & 2010 & Zhai & China & $115 / 3580$ & $48 / 96$ & $\mathbf{5 0} \%$ & $83 \%(96 / 115)$ & \\
$(20)$ & 2010 & Kim & Korea & $159 / 11623$ & $37 / 140$ & $\mathbf{2 3} \% \mathbf{3 7 / 1 5 9}$ & $88 \%(140 / 159)$ & Healthy volunteers only \\
$(21)$ & 2010 & Ohba & Japan & $20 / 1501$ & $11 / 20$ & $\mathbf{5 5 \%}$ & $100 \%(20 / 20)$ & \\
\hline$(22)$ & 2012 & Bonabi & Swiss & $53 / 3062$ & $10 / 42$ & $\mathbf{2 4} \%$ & $80 \%(42 / 53)$ & \\
\hline
\end{tabular}

Note: Study by Kwak et al. (18) in the Bertagna et al. (13) meta-analysis cannot be considered in this analysis of thyroid incidentaloma studies as patients in that study were selected based on ultrasound positivity for a nodule in the thyroid, and only then checked for any positron emission tomography/computed tomography imaging and positivity. Thus only a small subset of positron emission tomography/computed tomography thyroid incidentalomas were included by the authors 
or why certain patients were chosen for biopsy, but it is reasonable to assume that those selected for biopsy had a high clinical or imaging suspicion for malignancy. Soelberg et al. (12) admitted in their meta-analysis: "One cannot exclude that surgical confirmation was most likely obtained in those patients with the highest likelihood of malignancy and therefore the malignancy risk of focal uptake is overestimated". We suspect that the reported average malignancy rate of $35 \%$ in the literature is overestimated and that the actual value is significantly lower.

An overview of the largest meta-analysis done by Bertagna et al. (13) (27 studies) reveals that the lowest malignancy rates are reported by studies with the highest biopsy rates. This pattern has not been noted either by Bertagna et al. (13) or the other two meta-analyses. We examined all papers with a biopsy rate of over $80 \%$ and further analyzed the available data (Table 7). Studies by Chen et al. (16) and Ohba et al. (21) were excluded as they were done on healthy volunteers only, and the study by Zhai et al. (19) was excluded as the patient population was unspecified. This leaves only four studies of oncologic patients with thyroid incidentalomas with high biopsy rates of more than $80 \%$. These studies showed malignancy rates of $10 \%(14)$, $14 \%(17), 23 \%(20)$ and $24 \%(22)$. It is worth noting that the only North American study published in the literature with a high biopsy rate showed a malignancy rate of $14 \%$ (17), very close to our rate of $11 \%$.

In our cohort of 128 thyroid incidentaloma patients, there was a statistically significant difference between the SUV $V_{\text {max }}$ values of benign thyroid incidentalomas (median SUV $\max$ 4.8) and malignant incidentalomas (median SUV $\max 6.3$ ), however, there was a wide overlap of SUV $\max$ values between the two groups. An ROC curve was generated, however no suitable SUV $_{\max }$ cut-off value was
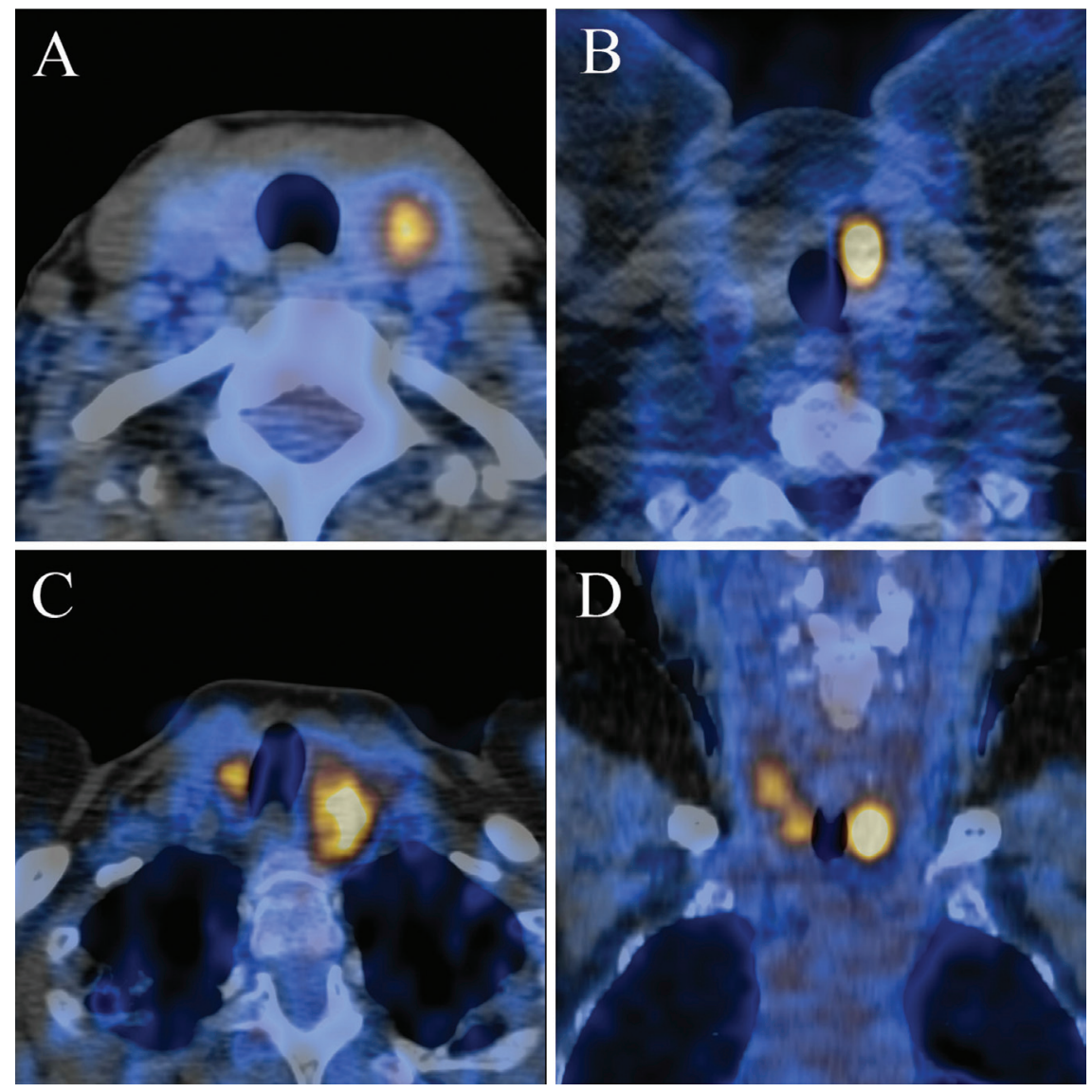

Figure 2. Four cases of incidental focal 18F-FDG uptake in the thyroid. Transaxial PET/CT fusion image of a benign left thyroid incidentaloma in a 52-year-old woman with a prior history of cervical cancer, with SUV ${ }_{\max } 4.4$, biopsied to reveal a benign follicular lesion (A), transaxial PET/CT fusion image of a malignant left thyroid incidentaloma in a 40-year-old man with a prior history of melanoma, with SUV $V_{\max } 11.8$, biopsied to reveal a papillary carcinoma follicular variant (B). Transaxial PET/CT fusion image of a bilateral focal benign thyroid incidentaloma in a 65-year-old woman with a prior history of lymphoma, with SUV $\max 7.8$ of left lesion and SUV $\max 6.4$ of right lesion, biopsied to reveal benign nodular hyperplasia (C), coronal PET/CT fusion image of a bilateral malignant thyroid incidentaloma in a 70-year-old woman with a prior history of colorectal carcinoma, with SUV $\mathrm{max} 8.1$ in the left lesion and SUV $\max 4.5$ in the right lesion, biopsied to reveal a multifocal papillary carcinoma, classical variant on a background of Hashimoto's thyroiditis (D) 
found to be useful in differentiating benign from malignant thyroid incidentalomas (Figure 1). This is in agreement with all three meta-analyses, all of which found a statistically significant difference between SUV $V_{\max }$ of benign lesions vs malignant lesions, with a wide overlap and no clear $S U V_{\max }$ cut-off value, or role for the use of SUV $V_{\max }$ to differentiate benign from malignant thyroid incidentalomas.

In our clinically followed group (71 of 128 patients), 29 of $71(41 \%)$ patients also had a follow-up PET/CT and incidental thyroid uptake was re-evaluated on the followup PET/CT. Interestingly, although all 29 patients were determined to have benign thyroid incidentalomas on long term clinical follow-up, 8 of 29 (28\%) follow-up PET/CTs showed increased $S U V_{\max }$ in the thyroid incidentaloma (defined as any increase over the previous $S U V_{\max }$ value), with the rest showing equal or lower $S U V_{\text {max }}$, suggesting that increasing SUV $V_{\max }$ on a follow-up PET/CT may not be helpful in assessing whether a thyroid incidentaloma was benign or malignant, and therefore a follow-Up PET/CT is unlikely to be a useful imaging modality to monitor and follow thyroid incidentaloma patients. Further research in this area is needed to determine the optimal management of thyroid incidentaloma patients.

\section{Study Limitations}

A limitation of our study was that only 57 of 128 thyroid incidentaloma patients (45\%) were biopsied. Ideally, a thyroid incidentaloma study would be prospective and all 18F-FDG positive focal thyroid incidentalomas would have biopsy results available. However, unlike most studies that had not evaluated or followed thyroid incidentaloma patients who were not biopsied, our 71 patients who were not biopsied were followed for at least 12 months.

\section{Conclusion}

18F-FDG positive focal thyroid incidentalomas occurred in $2.2 \%$ of oncologic PET/CT scans, and of these, $10.9 \%$ were malignant. This is the lowest malignancy rate reported in a North American study and second lowest in the world to date, and is much lower than the average $33-35 \%$ malignancy rate reported in recent systematic reviews. Higher reported malignancy rates in the literature may be the result of selection bias. The decision to biopsy a thyroid incidentaloma should be deferred in the absence of a high clinical or imaging suspicion of malignancy. Recommendations to biopsy all 18F-FDG positive focal thyroid incidentalomas should not be followed until further research is available. We suspect that the true malignancy rates of thyroid incidentalomas are in the $10-20 \%$ range, rather than 35\% (or higher) range which is often quoted in the literature. SUV max values cannot be used to differentiate benign from malignant thyroid incidentalomas, and follow-up PET/CT may not be useful in monitoring these patients. Future studies should be prospective and biopsy rates should be as high as possible, to avoid selection bias that may significantly impact reported malignancy rates.

\section{Acknowledgements}

The authors would like to thank Dr. Robert Battat, Dr. James Curtis and Dr. Han Zeng for their assistance in data collection and processing.

\section{Ethics}

Ethics Committee Approval: Retrospective study. Informed Consent: Retrospective study.

Peer-review: Internally peer-reviewed.

\section{Authorship Contributions}

Concept: W.M., Design: W.M., A.C., Data Collection and Processing: A.C., Analysis and interpretation: W.M., A.C., Literature Search: W.M., A.C., Writing: W.M., A.C.

Conflict of Interest: No conflict of interest was declared by the authors.

Financial Disclosure: The authors declared that this study received no financial support.

\section{References}

1. Cook GJ, Fogelman I, Maisey MN. Normal physiological and benign pathological variants of 18-fluoro-2-deoxyglucose positron emission tomography scanning: potential for error in interpretation. Semin Nucl Med 1996;26:308-314.

2. Bakheet SM, Powe J. Benign causes of 18-FDG uptake on whole body imaging. Semin Nucl Med 1998;28:352-358.

3. Kostakoglu L, Hardoff R, Mirtcheva R, Goldsmith SJ. PET-CT fusion imaging in differentiating physiologic from pathologic FDG uptake. Radiographics 2004;24:1411-1431.

4. Israel O, Yefremov N, Bar-Shalom R, Kagana O, Frenkel A, Keidar $Z$, Fischer D. PET/CT detection of unexpected gastrointestinal foci of 18F-FDG uptake: incidence, localization patterns, and clinical significance. J Nucl Med 2005;46:758-762.

5. Tatlidil R, Jadvar H, Bading JR, Conti PS. Incidental colonic fluorodeoxyglucose uptake: correlation with colonoscopic and histopathologic findings. Radiology 2002;224:783-787.

6. Litmanovich D, Gourevich K, Israel O, Gallimidi Z. Unexpected foci of 18F-FDG uptake in the breast detected by PET/CT: incidence and clinical significance. Eur J Nucl Med Mol Imaging 2009;36:15581564.

7. Choi JY, Lee KS, Kim HJ, Shim YM, Kwon OJ, Park K, Baek CH, Chung $J \mathrm{H}$, Lee KH, Kim BT. Focal thyroid lesions incidentally identified by integrated 18F-FDG PET/CT: clinical significance and improved characterization. J Nucl Med 2006;47:609-615.

8. Han EJ, HOJ, Choi WH, Yoo IR, Chung SK. Significance of incidental focal uptake in prostate on 18-fluoro-2-deoxyglucose positron emission tomography CT images. Br J Radiol 2010;83:915-920.

9. Metser U, Miller E, Lerman H, Lievshitz G, Avital S, Even-Sapir E. 18F-FDG PET/CT in the evaluation of adrenal masses. J Nucl Med 2006;47:32-37.

10. Basu S, Houseni M, Alavi A. Significance of incidental fluorodeoxyglucose uptake in the parotid glands and its impact on patient management. Nucl Med Commun 2008;29:367-373.

11. Shie P, Cardarelli R, Sprawls K, Fulda KG, Taur A. Systematic review: prevalence of malignant incidental thyroid nodules identified on fluorine-18 fluorodeoxyglucose positron emission tomography. Nuc Med Comm 2009;30:742-748. 
12. Soelberg KK, Bonnema SJ, Brix TH, Hegedüs L. Risk of malignancy in thyroid incidentalomas detected by $18 \mathrm{~F}$-fluorodeoxyglucose positron emission tomography: a systematic review. Thyroid 2012;22:918-925.

13. Bertagna F, Treglia G, Piccardo A, Giubbini R. Diagnostic and clinical significance of F-18-FDG PET/CT thyroid incidentalomas. J Clin Endocrinol Metab 2012;97:3866-3875.

14. Hsieh HJ, Lin SH, Yang BH, Chu YK, Chang CP, Liu RS. The clinical relevance of thyroid incidentalomas detected by 18F-fluorodeoxyglucose positron emission tomography. Ann Nucl Med Sci 2003;16:53-58.

15. Chen W, Parsons M, Torigian DA, Zhuang H, Alavi A. Evaluation of thyroid FDG uptake incidentally identified on FDG PET/CT imaging. Nucl Med Commun 2009;30:240-244.

16. Chen YK, Ding HJ, Chen KT, Chen YL, Liao AC, Shen YY, Su CT, Kao CH. Prevalence and risk of cancer of focal thyroid incidentaloma identified by $18 \mathrm{~F}$-fluorodeoxyglucose positron emission tomography for cancer screening in healthy subjects. Anticancer Res 2005;25:1421-1426.

17. King DL, Stack BC Jr, Spring PM, Walker R, Bodenner DL. Incidence of thyroid carcinoma in fluorodeoxyglucose positron emission tomography-positive thyroid incidentalomas. Otolaryngol Head Neck Surg 2007;137:400-404.
18. Kwak JY, Kim EK, Yun M, Cho A, Kim MJ, Son EJ, Oh KK. Thyroid incidentalomas identified by 18F-FDG PET: sonographic correlation. AJR Am J Roentgenol 2008;191:598-603.

19. Zhai G, Zhang M, Xu H, Zhu C, Li B. The role of $18 F-$ fluorodeoxyglucose positron emission tomography/computed tomography whole body imaging in the evaluation of focal thyroid incidentaloma. J Endocrinol Invest 2010;33:151-155.

20. Kim BH, Na MA, Kim IJ, Kim SJ, Kim YK. Risk stratification and prediction of cancer of focal thyroid fluorodeoxyglucose uptake during cancer evaluation. Ann Nucl Med 2010;24:721-728.

21. Ohba K, Nishizawa S, Matsushita A, Inubushi M, Nagayama K, Iwaki $H$, Matsunaga $H$, Suzuki S, Sasaki S, Oki Y, Okada H, Nakamura $\mathrm{H}$. High incidence of thyroid cancer in focal thyroid incidentaloma detected by $18 \mathrm{~F}$-fluorodeoxyglucose [corrected] positron emission tomography in relatively young healthy subjects: results of 3-year follow-up. Endocr J 2010;57:395-401.

22. Bonabi S, Schmidt F, Broglie MA, Haile SR, Stoeckli SJ. Thyroid incidentalomas in FDG PET/CT: prevalence and clinical impact. Eur Arch Otorhinolaryngol 2012;269:2555-2560. 